\title{
PLANTING DATE IN RELATION TO CASSIDA VITTATA VILL. (COLEOPTERA: CHRYSOMELIDAE) INFESTATION AND YIELD COMPONENTS IN SUGAR BEET FIELDS
}

\author{
EL-SERWY, S. A. \\ Plant Protection Research Institute, ARC, Dokki,Giza
}

(Manuscript received 27 November 2008)

\begin{abstract}
The tortoise beetle, Cassida vittata Vill., (Coleoptera: Chrysomelidae) is a serious pest on sugar beet causes losses in root yield and sugar content in Egypt. In this work, five field free of pesticides planted (with Raspoly sugar beet variety) at five different dates through August to October 2005 were chosen at Shirbin, Dakahlyia governorate, in 2005- 2006 season. In each field, yield components and level \& intensity of infestation were determined. These findings were greatly varied according to sowing date, sugar beet planted during the first half of August had a low yield (18.6 tons / fed.) with $19.5 \%$ sugar content. The yield increased progressively with delaying the date to reach 29.8 tons/fed. with $18.1 \%$ sugar content for October 1 plantation. The late plantation of October 20 harbored a light yield (19.6 tons /fed.) with the lowest sugar content (17.9\%). The infestation firstly appeared in a low level of $10 \%$ infested leaves and 7.6 pores / 4 leaf discs on September, reached $100 \%$ and 45.2 pores in the last plantation. Also, the estimated highest average of income loss was found in the late plantations as about 1493 L. E. / feddan (about 32.5\%) when compared with the free infested early plantations during August. On the other hand, the plantations of September 15 and October 1 received light infestation and low pores recognized the highest income. Therefore, early planting during August and September, could be followed for sugar beet crop as one of the best agricultural control method
\end{abstract}

\section{INTRODUCTION}

Sugar beet, Beta vulgaris L., is the second sugar crop in Egypt. This crop faces several problems that reduce its yield, of which the tortoise beetle, Cassida vittata Vill.. Few studies pertaining to the effect of planting dates on the infestation by this pest (Awadalla et al, 1992 Salama \& Elnagar, 1992, and Aly et al, 1993). Several authors contributed to damage caused by larvae and adults of $C$. vittata, losses in root yield and economic threshold level on sugar beet plants, Metwally et al, 1987, Mostafa et al, 1992, Ebieda et al, 1996, Ebieda 1997 and Bassyouny, 1998 in Egypt and Nadif, 2007 in Morocco. The present study initiated to study the effect of five 
planting dates on level and intensity of infestation by this beetle and losses in yield components and return at Shirbin region in Dakahlyia governorate during 2005- 2006 sugar beet growing season.

\section{MATERIALS AND METHODS}

Five fields, owned to farmers, ranged from 800 to $4200 \mathrm{~m}^{2}$, planted with Raspoly sugar beet variety were chosen at Shirbin, Dakahlyia governorate, 2005-2006 season. These fields were planted on August, 10 and 28, September, 15 and October 1 , and 20 and not received any insecticidal application till harvest. To obtain level of infestation and feeding pores density, thirty leaves were collected randomly from each field on the day before harvest and transferred directly to the laboratory. All leaves in each date were separately classed as pored (infested) or non pored (not infested). Four discs ( $2 \times 2 \mathrm{~cm}$, each) were randomly selected and cut off from each infested leaf to record number of feeding pores in each.

Data concerning root yield and sugar \% content as well as price per ton and income as L.E. per feddan $\left(=4200 \mathrm{~m}^{2}\right)$ for each field were obtained from the administration of the sugar factory at Abou Madi.

\section{RESULTS AND DISCUSSION}

Data in Table (1) show that, the sugar beet fields were harvested after the recommended period (180- 210 days of plant age).

The root yield and percentage of sugar content as well as infestation level and density of feeding pores were greatly varied according to sowing date. Sugar beet planted during the first half of August had a lower yield (18.6 tons / fed.) with 19.5\% sugar content (Table 1). The yield increased progressively to 19.9, 26.0 and 29.8 tons/fed. in the fields planted on August 28, September 15 and October 1, respectively, but lowered to 19.6 tons/fed. in the field planted on October 20. Sugar content averaged 20.7 and $19.5 \%$ in case of August 28 and September plantations, but decreased to 18.1 and $17.9 \%$ in October plantations. The infestation started in a low level as $10 \%$ infested leaves and 7.6 pores / 4 leaf discs on September, 15 plantation (Table 1). These findings increased to 12 and $100 \%$ and 12.8 and 45.2 pores in the last two plantations, respectively.

As for the economic view, the early plantation, during the first half of August, achieved the highest price (260 L.E. / ton) and a reasonable return 4836 L.E. / feddan. The price decreased to 230, 200,167 and 164/ton in the followed four plantations, respectively. 
Data in the same Table revealed that, September 15 and October 1 represented the best dates for planting the sugar beet. $C$. vittata could be minimized infestation to $10 \& 12 \%$ infested leaves and $7.6 \& 12.8$ pores/ 4 leaf discs and, in the same time, recognized the highest income (4977 and 5200 L. E. / feddan). Ebieda (1997) reported that, the tortoise beetle affected to a great extend the leaves of sugar beet plants, whereas the roots and sugar beet yields were less affected which may be due to the compensation character of sugar beet plants. The late plantation (on October 20) received the sever infestation, all leaves were infested, with 45.2 pores/4 leaf discs. Also, a light yield with the lowest sugar content (17.9\%) was gained. So, the least income was achieved in this plantation as 3214 L. E./ only. The estimated average of income loss was about 1493 L. E. / feddan (about 32.5\%) when compared with the free plantations.

In conclusion, sugar beet yield components were greatly varied by delaying sowing date as well as the level and intensity of infestation by C. vittata. Early plantations during August escaped from infestation had lower yield and highest sugar content, achieved the highest price per ton and reasonable return per feddan. On contrary, late plantation on October 20 inhabit sever infestation either in level or density of feeding pores, had lower yield and lowest sugar content, harbored the lowest price per ton and return per feddan. However, September and early October plantations inhabit low level and feeding pores density achieved the highest yield and return. Therefore, early planting during August and September, could be recommended for sugar beet crop to avoid the side effect of insecticides and conserve and promote natural enemies as one of the best agricultural control method. This result coincides with the findings of Salama \& El-Nagar, 1992 and Aly et al, 1993.

\section{ACKNOWLDGEMENT}

The author wishs to thank Dr G. Khadr ( Plant Protection Research Institute, Agricultural Research Center, Giza, Egypt) for revising the manuscript. 
Table 1. Effect of different sowing dates on sugar beet yield components, level and intensity of infestation by $C$. vittata and financial income at Shirbin during 2005- 2006 sugar beet growing season.

\begin{tabular}{|c|c|c|c|c|c|c|c|c|}
\hline \multicolumn{2}{|c|}{ Sowing date } & \multirow{2}{*}{$\begin{array}{c}\text { Plant age* } \\
\text { (day) } \\
\end{array}$} & \multirow{2}{*}{$\begin{array}{c}\text { Infested leaves } \\
(\%) \\
\end{array}$} & \multirow{2}{*}{$\begin{array}{c}\text { Pores/ } \\
4 \text { leaf discs } \\
\end{array}$} & \multirow{2}{*}{$\begin{array}{c}\text { Roots } \\
\text { (ton /fed.) }\end{array}$} & \multirow{2}{*}{ Sugar content (\%) } & \multirow{2}{*}{$\begin{array}{l}\text { Price / ton } \\
\text { (L. E. ) }\end{array}$} & \multirow{2}{*}{$\begin{array}{c}\text { Income/ fed } \\
\text { (L.E.) }\end{array}$} \\
\hline Month & Day & & & & & & & \\
\hline \multirow{2}{*}{ August } & 10 & 180 & 0 & 0.0 & 18.6 & 19.5 & 260 & 4836 \\
\hline & 28 & 207 & 0 & 0.0 & 19.9 & 20.7 & 230 & 4577 \\
\hline September & 15 & 200 & 10 & 7.6 & 26.0 & 19.5 & 200 & 5200 \\
\hline \multirow{2}{*}{ October } & 1 & 202 & 12 & 12.8 & 29.8 & 18.1 & 167 & 4977 \\
\hline & 20 & 187 & 100 & 45.2 & 19.6 & 17.9 & 164 & 3214 \\
\hline
\end{tabular}

* At harvest 


\section{REFERENCES}

1. Aly, F. A., M. A. Samy, F. E. El-Adl and S. M. Ibrahim 1993. Effect of planting dates on the infestation ratio of the main insects in sugar beet fields. J. Agric. Sci., Mansoura Univ., 18(6): 1805- 1812.

2. Awadalla, S. S., M.E. Ragab and L.A. El-Batran. 1992. Insect infestation levels of sugar beet plants in relation to varieties and planting dates. J. Agric. Sci., Mansoura Univ., 17 (5): 1121- 1126.

3. Bassyouny, A. M. 1998. Economic injury level of the main defoliator insects on sugar beet plants. J. Agric. Sci. Mansoura Univ., 23 (1): 405-418.

4. Ebieda, A. M. M., M. A. Hassanein and A. G. Solouma. 1996. Studies on sugar beet pests. IV. Biophysiological parameters and new approaches of tortoise beetle, Cassida vittataVill. and beet fly Pegoya mixta Vill. Annals of Agric. Sc. Moshtohor, 34 (3): 1213- 1228.

5. Ebieda, A. M. M. 1997. Studies on sugar beet pests. V. Effect of the tortoise beetle, Cassida vittata Vill. (Coleoptera: Chrysomelidae) on sugar beet with special reference to the determination of its economic threshold. Adv. Agric. Res. 2(1): 1-11.

6. Fedorenko, V. P. 2006. The most important sugar beet pests in Ukraine and integrated measures for their control. Proc.Nat. Sci. Matica Srpska Novi. Sad. 110: 21-38.

7. Metwally, S. M. I., R. El-Sufty, N. El- Dakhakhny and A. Bassyouny. 1987. Effect of infestations with certain insect pests on some sugar beet properties. J. Agric. Res. Tanta Univ., 13(4): 1119- 1128.

8. Mostafa, F. F., R. A. K. Salama, L. A. Hemida and S. Elnagar. 1992. Foliage consumption by tortoise beetle, Cassida vittata Vill. and economic injury level to sugar beet yield. Fayoum J. Agric. Res.\& Dev., 6 (1): 14- 24.

9. Nadif, A. 2007. Cassida vittata and Erwinia sp: Main enemies of sugar beet in the Gharb region. 70 th IIRB Congress, 11- 13 April-Marrakech: (English abstract).

10. Salama, R. A. K. and S. Elnagar. 1992. The tortoise bettle, Cassida vittata Vill. (Coleoptera: Chrysomelidae), a possible pest of sugar beet plantations in Egypt. J. Appl. Ent., 113: 88-92. 


\section{علاقة موعد الزراعة بالإصابة بخنفساء البنجر السلحفائية}

\section{ومكونات المحصول في حقول بنجر السكر.}

\section{سمير عوض السروى}

معهُ بحوث وقاية النباتات-مركز البحوث الزراعية- دقى- جيزة

تعتبر خنفساء البنجر السلحفائية من رتبـة غمدية ألأجنحة وفصيلة كرايسوميليدى آفة خطيرة

تحدث خسائر في حقول بنجر السكر من حيث محصول الجذور ونسبة السكر في مصر .أختير خمسة

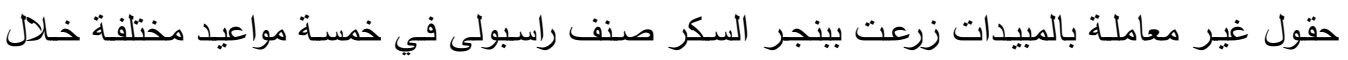

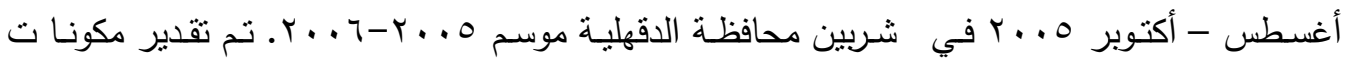

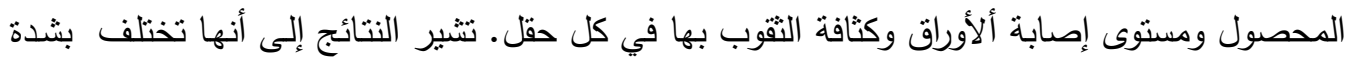

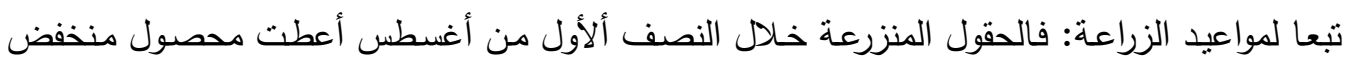
(1)،77)

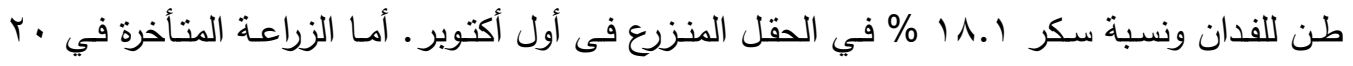

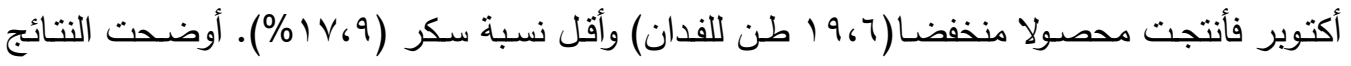

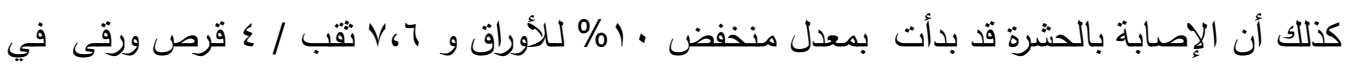

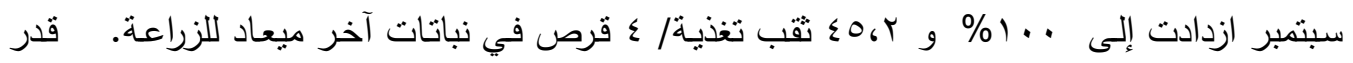

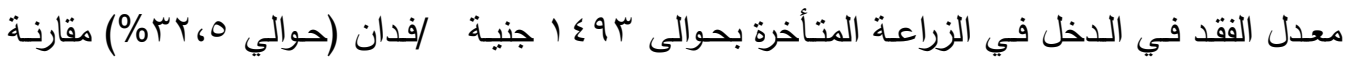

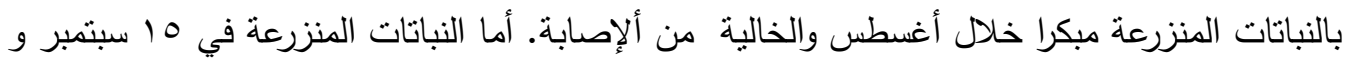

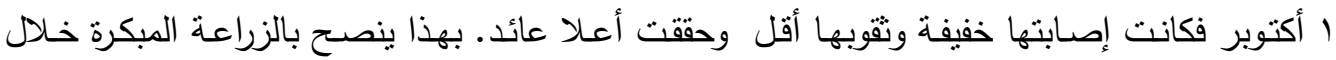
أغسطس وسبتمبر كأحدي طرق المكافحة الزراعية لخنفساء البنجر السلحفائية في حقول بنجر السكر . 
